\title{
Gaya Bahasa Pengunjung Hotel dan Restoran dalam Menyikapi New Normal Covid 19 Melalui Telepon
}

\author{
Fridska Hartaty Br Galingging \\ Universitas Indraprasta PGRI \\ Jalan Nangka No. 58 C/TB. Simatupang, Tanjung Barat, Jakarta Selatan 12530
}

fridska_h@yahoo.com

\begin{abstract}
This study aims to analyze and determine the extent of the language style of hotel and restaurant visitors in responding to the new normal covid 19 by telephone in Setiabudi District, South Jakarta. The research hypotheses tested include: 1) The relationship between the language style of hotel and restaurant visitors in the current situation. 2) By taking calls and calling hotel and restaurant visitors, we can find out what are the reasons which attract them to come back. 3) The language style of visitors in responding to the new normal covid 19. The study was conducted using a qualitative descriptive method. The research objects are the visitors of hotels and restaurants in Setiabudi Subdistrict, South Jakarta by telephone, using triangulation (combined) data collection techniques, namely observation, interviews, and documentation. The research instrument used was the researcher himself and the data from the conversation on the telephone that had been examined. The writer found that there were 15 meanings of hyperbolic language style, there were 13 meanings of personification and metaphoric language styles, for the simile language style there were 7 meanings, and the least was the litotes style language that has 2 meanings. The results of the study can be concluded as follows: 1) The existence of a relationship between the language style of hotel and restaurant visitors in the current situation can be seen from the language style that influences it, this is evidenced by the number of hotel and restaurant visitors who use hyperbole language style, there are 15 meanings. 2) Can find out why guests want to come back, this is proven by receiving calls and calling hotel and restaurant visitors. 3) It was found that there were various kinds of language styles of hotel and restaurant visitors in responding to the new normal covid 19, this was evidenced by the various language styles used. The results of this study are useful for improving the quality of learning and improving reasoning of language styles in telephone among the general public.
\end{abstract}

Keywords: language style, hotel dan restaurant visitors.

\begin{abstract}
Abstrak
Penelitian bertujuan untuk menganalisis dan mengetahui sejauh mana gaya bahasa para pengunjung hotel dan restoran dalam menyikapi new normal covid 19 melalui telepon di Kecamatan Setiabudi Jakarta Selatan. Hipotesis penelitian yang diuji meliputi: 1) Keterkaitan gaya bahasa para pengunjung hotel dan restoran dalam situasi saat ini. 2) Dengan menerima telepon dan menelepon pengunjung hotel dan restoran, kita bisa mengetahui alasan apa agar mau datang kembali. 3) Gaya bahasa pengunjung dalam menyikapi new normal covid 19. Penelitian dilakukan dengan metode deskriptif kualitatif. Obyek penelitian adalah pengunjung hotel dan restoran di Kecamatan Setiabudi Jakarta Selatan melaui telepon, dengan teknik pengumpulan data secara triangulasi (gabungan) yaitu observasi, wawancara, dan dokumentasi. Instrumen penelitian yang digunakan yaitu peneliti sendiri dan data hasil dari percakapan di telepon yang telah di teliti gaya bahasanya ada sebanyak 15 makna gaya bahasa hiperbola, ada 13 makna gaya bahasa personifikasi dan metafora, untuk gaya bahasa simile ada 7 makna, dan yang paling sedikit gaya bahasa litotes ada 2 makna. Hasil penelitian dapat diperoleh kesimpulan sebagai berikut: 1) Adanya keterkaitan dari gaya bahasa pengunjung hotel dan restoran dalam situasi saat ini dapat terlihat dari gaya bahasa yang mempengaruhinya, hal tersebut dibuktikan dengan banyaknya pengunjung hotel dan
\end{abstract}

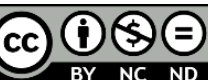

Creative Commons Attribution-NonCommercial-NoDerivatives 4.0 International License 
restoran yang menggunakan gaya bahasa hiperbola ada 15 makna. 2) Bisa mengetahui alasan tamu untuk mau datang kembali, hal tersebut dibuktikan dengan menerima telepon dan menelepon pengunjung hotel dan restoran. 3) Ditemukan berbagai macam gaya bahasa pengunjung hotel dan restoran dalam menyikapi new normal covid 19, hal tersebut dibuktikan dengan terdapatnya beragam gaya bahasa yang digunakan. Hasil penelitian ini berguna untuk meningkatkan kualitas pembelajaran dan meningkatkan penalaran akan gaya bahasa dalam bertelepon dikalangan umum.

Kata Kunci: gaya bahasa, pengunjung hotel dan restoran.

\section{PENDAHULUAN}

Dunia saat ini sedang diperhadapkan dengan virus yang tidak terlihat, tapi bila terkena dapat menyebabkan penyakit yang menakutkan di masyarakat. Diharapkan masyarakat dapat menjaga kesehatan dan mengikuti aturan new normal sesuai protokol covid-19 demi putusnya mata rantai virus ini (Baharudin dan Rumpia, 2020). Hal ini menjadi kebiasaan baru dengan mengenali ilmu pengetahuan dan kesehatan akan penyakit korona seseorang mampu menjalani kehidupan yang serba hygiene, sedangkan penguasaan terhadap nilai-nilai kebersihan dengan mencuci tangan, memakai masker dan menjaga jarak menjadikan kehidupan lebih terjaga dan teratur. Ini harus menjadi kegiatan yang dilakukan setiap hari, dimanapun kita berada (Dipna, 2020 dalam https://tirto.id/apa-itu-new-normal-dan-bagaimana-penerapannya-saat-pandemicorona-fCSg)

"Covid-19 telah membawa perubahan, termasuk dunia pendidikan. Pendidikan bukan lagi urusan persiapan mencari kerja, melainkan mengestafetkan peradaban lebih baik ke generasi selanjutnya," ujar Gubernur Jawa Barat Ridwan Kamil dalam peringatan Hari Pendidikan Nasional di Gedung Pakuan, kota Bandung, Sabtu (2/5/2020). Hanya saja untuk sekolah dan perguruan tinggi masih melakukan penyesuaian. Penyesuaian tersebut tertuang dalam Surat Edaran Nomor 2 Tahun 2020 tentang Pencegahan dan Penanganan Covid-19 di lingkungan Kemendikbud, serta Surat Edaran Nomor 3 Tahun 2020 tentang Pencegahan Covid-19 pada Satuan Pendidikan. "Kalau angka 'reproduction' ini turun, maka Jakarta berhasil mengendalikan pergerakan Covid-19," kata Anies di Balai Kota Jakarta, Selasa (20/5). Dengan menunjukkan grafik penyebaran Covid19, semakin besar angka tersebut, maka tingkat penularannya pun terpantau tinggi. Sebelumnya Pemprov DKI Jakarta telah mengeluarkan dua kebijakan PSBB yang dimulai sejak 10 April 2020 sampai 23 April 2020 lalu. DKI kemudian kembali memperpanjang PSBB tahap kedua, selama 28 hari dari 24 April sampai 22 Mei 2020. Terakhir pada tahap ketiga, dimulai dari 24 Mei sampai 4 Juni 2020. Bulan Juni PSBB dilonggarkan atau dikenal dengan PSBB transisi, aturannya seperti angkutan beroperasional normal, tapi kapasitas hanya $50 \%$, perkantoran boleh buka namun kapasitas hanya 50\%. Anies menekankan, selama 14 hari ke depan, mulai tanggal 22 Mei hingga 4 Juni lalu adalah masa menentukan. Apakah angka reproduksi akan tetap bertahan, turun atau bahkan naik. "Bila dua pekan ke depan, sama-sama disiplin berada di rumah, menghindari kerumunan, menghindari interaksi, maka Insya Allah angka reproduksi akan turun," ucapnya. Gubernur DKI Jakarta Anies Baswedan mengaku tengah mempersiapkan regulasi protokol kesehatan untuk berbagai sektor, yang akan 
berlaku setelah Jakarta lepas dari Pembatasan Sosial Berskala Besar (PSBB), dan masih memproses dokumen protokol 'new normal' untuk DKI Jakarta ini. (https://jakarta.bisnis.com/read/20200526/77/1244867/new-normal-dki-jakartaanies-tunggu-evaluasi-psbb-iii-kelar-4-juni).

Kewaspadaan sangat penting untuk mencegah penularan. Lakukan langkah proteksi diri seperti menggunakan masker. Salah satu alat pelindung diri (APD) yang direkomendasikan adalah masker. Masker akan melindungi seseorang dari virus agen infeksius termasuk corona virus. Kesadaran tiap individu juga turut menekan penyebaran virus dalam suatu komunitas. New normal adalah sebuah perubahan budaya hidup yang dicanangkan pemerintah Republik Indonesia agar masyarakat dapat terbiasa dengan tatanan hidup normal yang baru untuk menghadapi penyebaran virus corona. "Tapi, kehidupan yang berbeda itu bukanlah kehidupan yang penuh pesimisme atau ketakutan. Kita kembalikan produktivitas kita dengan optimisme karena kita tetap menerapkan berbagai mekanisme pencegahan," kata Jokowi di Istana Merdeka, Jakarta, melalui akun Youtube Sekretariat Presiden, pada Jumat (15/5/2020) (Shabibie, dalam https://pusdiklat.kemdikbud.go.id/surat-edaran-nomor-2-tahun-2o2o-tentangpencegahan-dan-penanganan-coro-va-y-rus-d-sease-covid-19-di-kementerianpendidikan-dan-kebudayaan/

Hingga ketika hotel dan restoran yang merupakan bagian dari sektor industri dibuka, sebagian masyarakat mulai berdatangan. Tapi sebagian pengunjung masih belum berani untuk keluar rumah mengunjungi hotel dan restoran, baik untuk melakukan pertemuan dengan rekan bisnis maupun untuk menginap dan makan bersama. Dimana biasanya setiap weekend banyak pengunjung yang menginap di hotel bersama keluarganya, sebelum virus korona melanda. Hal ini ditunjukkan dengan banyaknya tanggapan dan gaya bahasa masyarakat pengunjung hotel dan restoran, ketika pihak hotel dan restoran memberitahukan informasi mengenai promo yang ada sebagai upaya untuk memikat para pengunjung melalui telepon, email dan sosial media lainnya. Supaya mereka mau datang kembali ke hotel dan restoran untuk melakukan pertemuan atau makan.

Resepsionis saat ini mempunyai peran strategis, karena perkembangan komunikasi yang begitu modern membuat resepsionis diwajibkan dengan mudah memberikan informasi mengenai pelayanan apa saja yang tersedia pada perusahaan kepada tamu-tamu yang datang ke perusahaan tempat ia bernaung, dan resepsionis dituntut untuk ikut serta mengembangkan citra perusahaan, mendukung keamanan perusahaan serta mempermudah pekerjaan pimpinan melalui pengaturan, pengelolaan waktu secara efektif dan efisien (Kurniawan, 2020). Penulis akan lebih menekankan pada gaya bahasa dari para pengunjung hotel dan restoran melalui telepon. Dengan melakukan telesales atau menelepon dan menerima telepon dari tamu-tamu yang pernah datang sesuai database yang ada, maupun tamu-tamu yang belum pernah datang ke restoran yang ada di Gran Melia Jakarta.

Secara umum gaya bahasa adalah pengaturan kata-kata dan kalimatkalimat oleh penulis atau pembicara dalam mengekspresikan ide, gagasan, dan pengalamannya untuk meyakinkan atau mempengaruhi pembaca atau pendengar. 
Gaya bahasa atau style menjadi masalah atau bagian dari diksi atau pilihan kata yang mempersoalkan cocok tidaknya pemakaian kata, frasa atau klausa tertentu untuk menghadapi situasi tertentu. Gaya adalah cara mengungkapkan diri sendiri, entah melalui bahasa, tingkah laku, berpakaian dan lain sebagainya (Keraf, 2010: 113). Gaya bahasa berarti cara tampil atau cara menampilkan diri. Karena bahasa dalam karya sastra berfungsi sebagai medianya atau perantaranya. Dengan gaya bahasa yang baik akan baiklah penilaian seseorang terhadapnya.

Hotel adalah suatu jenis akomodasi yang mempergunakan sebagian atau seluruh bangunan untuk menyediakan jasa penginapan, makanan dan minuman serta jasa penunjang lainnya bagi umum yang dikelola secara komersil. Pengertian tersebut diatas terdapat dalam peraturan yang dituangkan dalam Surat Keputusan Menparpostel No. KM. 37/ PW.340/ MPPT-86, tentang Peraturan Usaha dan Penggolongan Hotel. Menurut Lawson, "Hotel adalah sarana tempat tinggal yang dapat dimanfaatkan oleh para wisatawan dengan beberapa fasilitas pelayanan seperti jasa kamar, jasa penyedia makanan dan minuman, dan jasa akomodasi lainnya dengan syarat berupa imbalan ataupun pembayaran". (https://www.kompas.com/skola/read/2019/12/27/150000569/pengertian-hoteldan-karakteristiknya?page=all).

Sebuah restoran yang berada di dalam hotel harus memiliki fasilitasfasilitas standar. Oleh sebab itu, diberikan salah satu contoh yang sesuai dengan SK Menparpostel Nomor KM.37/PW.304/MPPT-86, tanggal 7 Juni 1986, Lampiran IIIA, untuk City Hotel dengan bintang empat (****) pada halaman 33 sampai dengan 35 (Sinaga 2018; Putri, 2018).

Sepengetahuan penulis, penelitian dengan topik yang diusung belumlah ada. Penelitian gaya bahasa cenderung pada bidang sastra. Misal, penelitian yang dilakukan oleh Rahmayanti, dkk. (2020). Hasil penelitian yang didapat adalah gaya bahasa yang terdapat dalam novel Pulang karya Tere Liye meliputi gaya bahasa personifikasi berjumlah $39,62 \%$ pengarang menggunakan gaya bahasa personifikasi untuk memberikan kesan hidup pada adegan-adegan ceritanya sehingga keseluruhan rangkaian ceritanya terkesan lebih menarik. Gaya bahasa metafora berjumlah 33,96\% pengarang menggunakan kiasan tertantang untuk membaca dan memahami maknanya. Gaya bahasa hiperbola berjumlah 26,42\% penggunaan gaya bahasa hiperbola dalam novel Pulang karya Tere Liye membuat rangkaian ceritanya mempunyai nilai rasa yang lebih kuat dan tajam.

Penelitian selanjutnya yang dilakukan oleh Susilowati (2016). Dalam penelitiannya menunjukkan bahwa: (1) Novel Pesantren Impian menggunakan gaya bahasa perbandingan dan gaya bahasa pertentangan; (2) Gaya bahasa perbandingan dalam novel Pesantren Impian mengandung sembilan jenis gaya bahasa perbandingan yaitu gaya bahasa simile, metafora, personifikasi, alegori, antitesis, pleonasme dan tautologi, perifrasis, dan koreksio. (3) Gaya bahasa pertentangan dalam novel Pesantren Impian mengandung tujuh jenis gaya bahasa pertentangan yaitu gaya bahasa hiperbola, litotes, inuendo, paradoks, klimaks, sinisme, dan sarkasme. (4) Gaya bahasa perbandingan yang dominan digunakan dalam novel Pesantren Impian adalah jenis gaya bahasa metafora yang berjumlah tiga puluh empat data gaya bahasa. (5) Gaya bahasa pertentangan yang dominan 
digunakan dalam novel Pesantren Impian adalah jenis gaya bahasa paradoks yang berjumlah tiga puluh tujuh data gaya bahasa.

Mengacu pada uraian di atas, penulis tertarik untuk melakukan penelitian dengan judul "Gaya Bahasa Pengunjung Hotel dan Restoran dalam Menyikapi New Normal Covid 19 Melalui Telepon". Penelitian ini bertujuan untuk mengetahui gaya bahasa apa yang sering digunakan masyarakat atau tamu hotel dan restoran dalam menyikapi new normal Covid 19, yang di berlakukan di hotel dan restoran sesuai protokol covid 19. Alasan apa yang diberikan dan seberapa besar kekhawatiran terhadap penularan Covid 19 dari para tamu.

\section{METODE}

Penulis menggunakan metode deskriptif kualitatif dalam menggambarkan keadaan yang sebenarnya yaitu mendeskriptifkan semua aspek gaya bahasa yang digunakan para pengunjung hotel dan restoran melalui telepon. Dengan metode ini, peneliti mendeskripsikan apa yang dilihat, didengar, dirasakan, dan ditanyakan. Data yang telah terkumpul cukup banyak, bervariasi dan belum tersusun secara jelas diidentifikasi, dianalisis, dideskripsikan, kemudian di interpretasikan sesuai dengan tujuan yang ditetapkan (Sugiyono, 2016).

Dalam penelitian kualitatif, yang menjadi instrumen atau alat penelitian adalah peneliti itu sendiri dan menggunakan buku catatan sebagai bagian dari instrumen penelitian. Teknik yang digunakan yaitu studi kasus. Berdasarkan teknik penelitian peneliti melakukan pengumpulan data yang digunakan secara sederhana, lalu menganalisis data, dan melakukan deskripsi bagian demi bagian yang ditemukan dalam penelitian.

\section{HASIL DAN PEMBAHASAN}

Hasil

Dari hasil analisis penelitian dalam Gaya Bahasa Pengunjung Hotel dan Restoan dalam Menyikapi New Normal Covid 19 Melalui Telepon dihasilkan data sebagai berikut: 


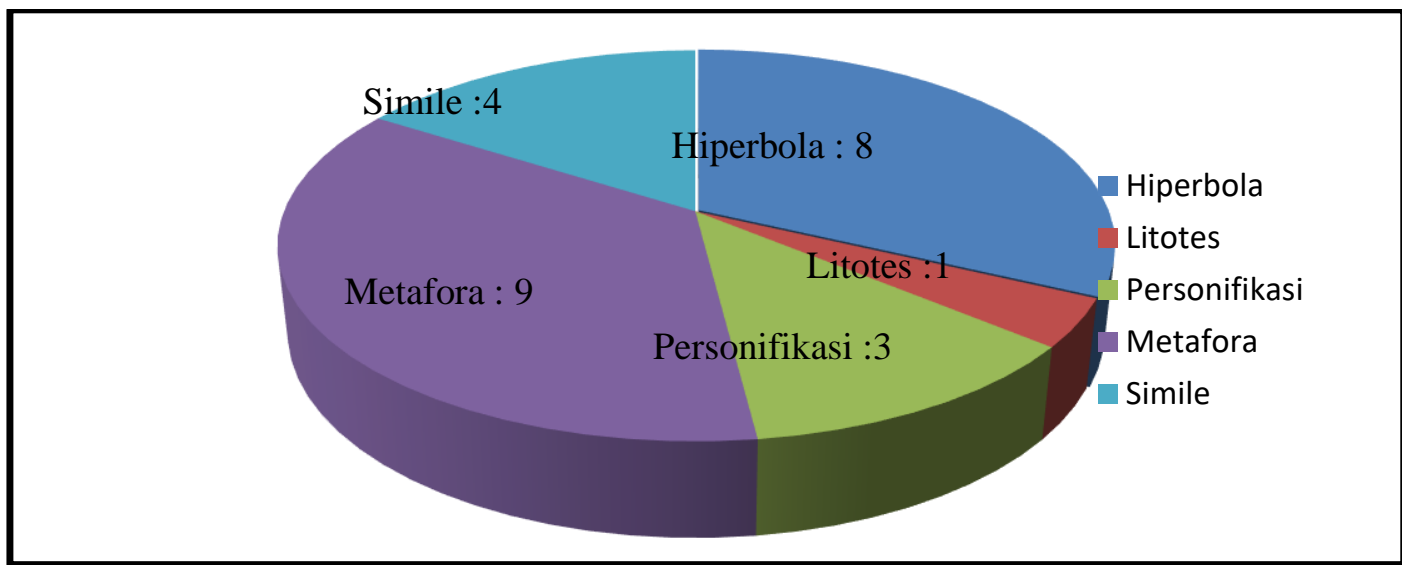

Gambar 1 Jenis Gaya Bahasa Pengunjung Hotel dalam Bahasa Sehari-hari Melalui Telepon Dalam Menyikapi New Normal Covid 19.

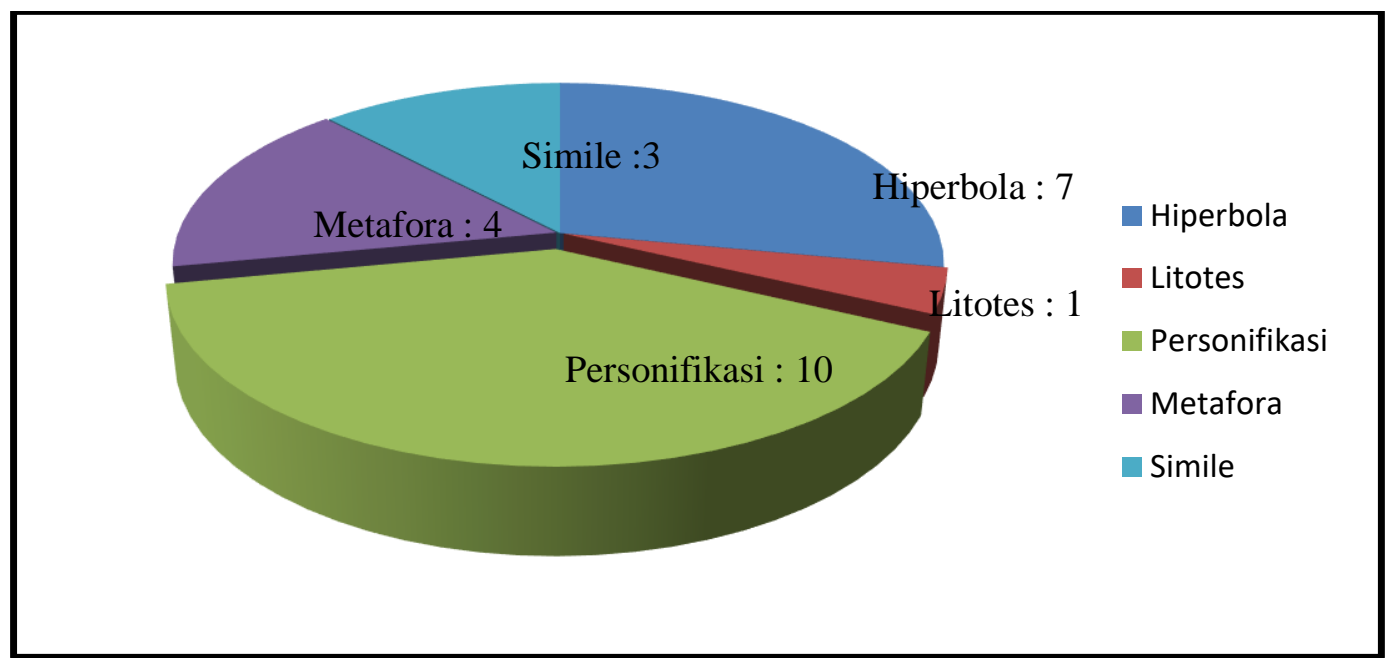

Gambar 2 Jenis Gaya Bahasa Pengunjung Restoran Dalam Bahasa Sehari-hari Melalui Telepon Dalam Menyikapi New Normal Covid 19.

\section{Pembahasan}

Ada berbagai macam jenis gaya bahasa yang digunakan oleh para pengunjung hotel Gran Melia Jakarta dalam sehari-hari melalui telepon. Sejak kemunculan virus corona di Indonesia, ada tamu yang meragukan kenyamanan hotel terutama dalam hal pelayanan kamar. Ketika pengunjung restoran hendak makan di restoran ada beberapa yang melakukan reservasi melalui telepon untuk memastikan keadaan restoran yang sudah sesuai aturan baru atau new normal.

\section{Gaya Bahasa Hiperbola}

Adalah semacam gaya bahasa yang mengandung suatu pernyataan yang berlebihan, dengan membesar-besarkan sesuatu hal (Keraf, 2009). 
Data pertama: ..."Apa promo shabu-shabunya lengkap? Jangan sampai pas saya datang banyak yang kurang menunya. Saya pencinta seafood lho mba. Apa kita bisa memasaknya sendiri bersama teman semeja?". Peneliti menjawab: "Promonya masih lengkap sama seperti dulu, hanya saja tidak bisa memasak sendiri. Ada staff kitchen nya yang akan memasakkan untuk bapak dan temanteman semeja." Penelepon: "Baik mba, saya mau reservasi untuk weekend, tapi semua sudah sesuai protokol kesehatan ya kan?" Peneliti menjawab: "Iya, sudah pak"...

Peneliti akan memaparkan penggalan dari percakapan diatas merupakan gaya bahasa pengunjung restoran pada saat menanyakan promo dan aturan yang berlaku di restoran. Gaya bahasa hiperbola dalam percakapan tersebut ada 7 makna, yaitu: 1. Adanya daya pengaruh yang kuat terhadap orang yang mendengar, 2. Mempunyai pengaruh yang kuat dalam meyakinkan penelepon, 3 . Melebih-lebihkan sesuatu, 4. Membesar-besarkan sesuatu, 5. Membandingkan secara tidak langsung, 6. Daya tarik seafood, 7. Penegasan kualitas makanan.

Data kedua: ..."Saya mau menginap disana, tapi kamarnya dibersihkan setiap hari gak mba? Sekarang kan covid ada dimana-mana harus serba hygene, semua nya di desinfektan gak?". Peneliti menjawab: "Iya ibu, setiap hari dibersihkan dan didesinfektan sudah terjamin kebersihannya." Penelepon: "Rencananya mau nginap untuk weekend nanti mba..."

Peneliti akan memaparkan dari percakapan diatas merupakan gaya bahasa pengunjung hotel dalam kebersihan kamar hotel. Gaya bahasa hiperbola dalam percakapan tersebut ada 8 makna, yaitu: 1. Melebih-lebihkan sesuatu, 2. Menggunakan kata-kata yang dramatis, 3. Mempunyai daya pengaruh yang kuat terhadap orang yang mendengarnya, 4. Memberikan efek tertentu bagi si pendengar, 5. Memberikan gambaran yang berlebihan, 6. Memberikan penekanan pada suatu situasi, 7. Meningkatkan kesan berlebihan, 8. Hal yang disampaikan lebih besar dari kenyataan.

\section{Gaya Bahasa Litotes}

Adalah semacam gaya bahasa yang dipakai untuk menyatakan sesuatu dengan tujuan merendahkan diri (Keraf, 2009).

Data ketiga: ..."Saya mau reserve mba untuk 4 orang nanti siang, menunya enak-enak kan mba? Soalnya buat atasan saya, saya gak ikut kesana nanti." Peneliti menjawab: "enak bu dijamin makanannya, ibu tidak ikut bergabung?." Penelepon: "Saya bukan orang penting mba, pegawai biasa. Biar atasan saya yang kesana beliau mau ketemu rekan kerjanya."...

Peneliti akan memaparkan dari percakapan diatas merupakan gaya bahasa pengunjung restoran dalam memesan tempat sekaligus menanyakan menu yang ada direstoran. Gaya bahasa litotes dalam percakapan tersebut ada 1 makna, yaitu: menyatakan sesuatu dengan tujuan untuk merendahkan diri.

Data keempat:..."Saya baru pertama kali menginap di hotel, karena diajak anak saya. Bingung cara pakai nya, takut salah juga mba. Namanya orang desa, jadi bingung cara pakainya. Semua serba diplastik mba." Peneliti menjawab: "Iya pak, kita sudah sesuaikan dengan aturan new normal jadi semua harus diplastik, agar terjamin kebersihannya. Semoga bapak senang menginap disini.”..

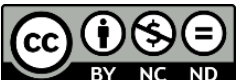

Creative Commons Attribution-NonCommercial-NoDerivatives 4.0 International License 
Peneliti akan memaparkan dari percakapan diatas merupakan gaya bahasa pengunjung hotel ketika memberikan kesan pertamanya menginap dihotel. Gaya bahasa litotes dalam percakapan tersebut ada 1 makna, yaitu: menggunakan katakata yang bersifat abstrak untuk menggambarkan suatu maksud dan tujuan dari isi cerita.

\section{Gaya Bahasa Personifikasi}

Adalah semacam gaya bahasa kiasan yang menggambarkan benda-benda mati atau barang-barang yang tidak bernyawa seolah-olah memiliki sifat-sifat kemanusiaan (Keraf, 2009).

Data kelima: ..."restorannya sudah sesuai dengan protokol kesehatan gak mba? Soalnya kami sudah usia lanjut, jadi kami mau memastikan semua sudah sesuai aturan yang berlaku sekarang." Peneliti menjawab: "Sudah ibu, semua sudah sesuai aturan new normal meja dan kursinya di desinfektan setiap hari dan jaga jarak." Penelepon: "Oh,syukurlah. Saya pernah lihat direstoran lain, tamunya ada yang tidak pakai masker, tapi tidak ditegur. Padahal masker kan melindungi dan menyelamatkan kita dari covid." Peneliti menjawab: "Iya bu, kami akan menegur tamu yang tidak memakai masker."...

Peneliti akan memaparkan dari percakapan diatas merupakan gaya bahasa pengunjung restoran ketika memastikan keadaan restoran disaat pandemi dan adanya pengunjung lain yang tidak memakai masker. Gaya bahasa personifikasi dalam percakapan tersebut ada 10 makna, yaitu: 1. Menggambarkan tentang suatu situasi dengan bayangan yang konkret, 2. Menggunakan pilihan kata yang memberikan suasana atau sifat manusia, 3. Menggambarkan benda mati yang tidak bernyawa seolah-olah memiliki sifat kemanusiaan, 4. Mengandung suatu unsur persamaan, 5. Memiliki gaya bahasa kiasan, 6. Masker disini benda mati yang seolah-olah berperilaku layaknya manusia, 7. Membandingkan benda mati selayaknya benda hidup, 8. Membuat pendengarnya menghargai sesuatu hal lain diluar diri mereka sendiri, 9. Mempererat rasa ketekaitan kita terhadap yang lain yang bukan manusia, 10. Memberikan sifat kemanusiaan pada benda mati.

Data Keenam: ..."ada harga promo gak kamarnya mba?. Saya sekeluarga mau menginap disana dua hari, kan lagi pandemi siapa tahu ada promo." Peneliti menjawab: "Iya bu, ada harga promo untuk 3 hari 2 malam 1.200 .000 belum termasuk sarapan pagi." Penelepon: "Boleh deh mba, (terdengar bunyi ambulans ) maaf ya mba ada ambulans nyanyi-nyanyi dia hahahaa.." Peneliti menjawab: "Iya bu, gak apa-apa suara ibu masih terdengar.”...

Peneliti akan memaparkan dari percakapan diatas merupakan gaya bahasa pengunjung hotel ketika ingin menginap. Gaya bahasa personifikasi dalam percakapan tersebut 3 makna, yaitu: 1. Menggambarkan tentang suatu situasi dengan bayangan angan yang konkret, 2. Menggunakan pilihan kata yang memberikan suasana atau sifat manusia pada suatu benda mati, 3 . Membandingkan benda mati, seolah-olah dapat berperilaku seperti manusia.

\section{Gaya Bahasa Metafora}

Adalah semacam analogi yang membandingkan dua hal secara langsung, tetapi dalam bentuk yang singkat (Keraf, 2009). 
Data ketujuh: ..."mba kamar hotelnya aman gak dari covid, soalnya sekarang virus corona sudah banyak memakan korban sampai ratusan ribu. Waktu itu saya pernah menginap di hotel lain, kamar nya terutama kamar mandinya kotor dan bau. Saya mau coba menginap disini, karena saya ada urusan kantor mau gak mau harus menginap disiniyang lebih dekat ke tempat kerja." Peneliti menjawab: "aman bu, di desinfektan setiap hari, sudah steril terjamin kebersihannya." Penelepon: "Bener ya mba,..."

Peneliti akan memaparkan dari percakapan diatas merupakan gaya bahasa pengunjung hotel dalam memastikan kenyaman saat menginap dihotel. Gaya bahasa metafora dalam percakapan tersebut ada 9 makna: yaitu: 1. Termasuk dalam majas perbandingan, 2. Memiliki kata-kata yang terbentuk menjadi kalimat imajinatif, 3. Tidak memiliki kata-kata pembanding secara langsung, 4. Mengungkapkan sesuatu secara langsung berupa perbandingan analogis, 5 . Gambaran seperti manusia yang butuh makan, virus corona sudah banyak memakan korban, 6. Adanya keraguan dari pengunjung, 7. Menegaskan suatu hal mengenai virus corona, 8. Menegaskan sesuatu yang muncul dari pemakaian gaya bahasa, 9. Menerangkan perasaan pengunjung saat ini.

Data kedelapan: ..."saya mau reservasi untuk hari Rabu jam 9 pagi ya mba, restorannya buka kan?." Peneliti menjawab: "Mohon maaf pak, restoran kita buka di Sabtu dan Minggu. Hari biasa tutup." Penelepon: "Oh, kalau begitu yang buka dimana mba?. Sekarang banyak restoran yang gulung tikar karena sepi pengunjung ya mba." Peneliti menjawab: "Restoran yang buka Yoshi jam 11 dan Lobby Lounge jam 7.”...

Peneliti akan memaparkan dari percakapan diatas merupakan gaya bahasa pengunjung restoran ketika akan melakukan pemesanan tempat untuk berkunjung. Gaya bahasa metafora dalam percakapan tersebut ada 4 makna, yaitu: 1. Mewakili hal lain yang bukan sebenarnya, 2. Sebagai gambaran yang berdasarkan persamaan atau perbandingan, 3. Dapat dipahami dengan mudah tanpa berpikir lama, 4. Memiliki kata-kata yang terbentuk menjadi kalimat imajinatif.

\section{Gaya Bahasa Simile}

Adalah perbandingan yang bersifat eksplisit. Yang dimaksud dengan perbandingan yang bersifat eksplisit ialah bahwa ia langsung menyatakan sesuatu sama dengan hal yang lain (Keraf, 2009).

Data kesembilan: ..."penyajian untuk makanan nya nanti seperti apa ya mba semenjak covid? Karena dulu kita bisa ambil sendiri, apa sudah di taruh di piring untuk setiap makanan nya kita tinggal ambil di buffet?." Peneliti menjawab: "makanan ya nanti diambilkan oleh staff dapurnya nya bu, ibu tinggal memilih mana yang mau ibu makan. Mengantri sesuai garis yang sudah dipasang di lantai." Penelepon: "Oh, tapi lengkap kan mba. Terus untuk bangkunya jaga jarak gak mba, karena dulu kita duduk berdekatan gak jauh-jauhan." Peneliti: "Jaga jarak bu, sesuai aturan new normal social distancing."...

Peneliti akan memaparkan dari percakapan diatas merupakan gaya bahasa pengunjung restoran ketika akan melakukan reservasi dengan protokol kesehatan di restoran. Gaya bahasa simile dalam percakapan tersebut ada 3 makna, yaitu: 1 . Menggunakan kata-kata penghubung "seperti", 2. Menggunakan kalimat yang 
membandingkan sesuatu, 3. Dinyatakan secara langsung sehingga orang lain dapat langsung mengerti maksudnya.

Data kesepuluh: ..."mba AC kamarnya bermasalah ya, atau remotnya yang bermasalah sangat dingin seperti tinggal di kutub saja." Peneliti menjawab: “ Baik bu, petugas kami akan segera datang ke kamar untuk melihat nya." ...

Peneliti akan memaparkan dari percakapan diatas merupakan gaya bahasa pengunjung kamar hotel saat melaporkan keadaan ruangan dikamar. Gaya bahasa simile dalam percakapan tersebut ada 4 makna, yaitu: 1. Dinyatakan secara eksplisit atau secara langsung sehingga orang lain dapat mengerti maksudnya, 2. Menggunakan kalimat atau suatu perumpamaan, 3. Menggunakan kata-kata penghubung "seperti", 4. Merupakan luapan dari isi pikiran dan perasaan diri melalui bahasa yang khas.

Dari semua percakapan pegunjung hotel dan restoran melalui telepon diatas, kebanyakan menggunakan gaya bahasa hiperbola karena sering membesarbesarkan sesuatu hal yang berlebihan. Jika ditotal ada sebanyak 15 makna gaya bahasa hiperbola, yang menggunakan gaya bahasa personifikasi dan metafora ada sebanyak 13 makna, gaya bahasa pengunjung hotel dan restoran yang menggunakan gaya bahasa simile ada 7 makna, dan yang menggunakan gaya bahasa litotes ada 2 makna.

Adanya keterkaitan dari gaya bahasa pengunjung hotel dan restoran dalam situasi saat ini dapat terlihat dari gaya bahasa yang mempengaruhinya. Ditemukan berbagai macam gaya bahasa pengunjung hotel dan restoran dalam menyikapi new normal covid 19. Dengan menerima telepon atau menelepon tamu atau pengunjung restoran dan hotel, kita bisa mengetahui alasan mereka untuk datang kembali dilihat dari gaya bahasa dalam kalimat diatas. Gaya bahasa pengunjung dalam menyikapi new normal covid 19 dapat terlihat dalam beberapa penjelasan diatas.

\section{SIMPULAN}

Berdasarkan uraian di atas, dapat disimpulkan bahwa sesuai dengan data yang diperoleh peneliti, Gaya Bahasa Pengunjung Hotel dan Restoran Dalam Menyikapi New Normal Covid 19 Melalui Telepon Di Kecamatan Setiabudi Jakarta Selatan, kesimpulannya adalah terdapat lima gaya bahasa sehari-hari yang digunakan pengunjung hotel dan restoran, yaitu: 1. Gaya bahasa hiperbola, 2. Gaya bahasa litotes, 3. Gaya bahasa personifikasi, 4. Gaya bahasa metafora, dan 5. Gaya bahasa simile. Jika ditotal ada sebanyak 15 makna gaya bahasa hiperbola, ada 13 makna yang menggunakan gaya bahasa personifikasi dan metafora, gaya bahasa pengunjung hotel dan restoran yang menggunakan gaya bahasa simile ada 7 makna, dan yang menggunakan gaya bahasa litotes ada 2 makna. Masingmasing memiliki makna yang berbeda-beda, dilihat dari bentuk gaya bahasa nya dalam setiap percakapan melalui telepon. Gaya bahasa yang paling banyak digunakan oleh pengunjung hotel dan restoran adalah gaya bahasa hiperbola. Adanya keterkaitan dari gaya bahasa pengunjung hotel dan restoran dalam situasi saat ini dapat terlihat dari gaya bahasa yang mempengaruhinya. Ditemukan 
berbagai macam gaya bahasa pengunjung hotel dan restoran dalam menyikapi new normal covid 19. Dengan menerima telepon atau menelepon tamu atau pengunjung restoran dan hotel, kita bisa mengetahui alasan mereka untuk datang kembali.

\section{DAFTAR PUSTAKA}

Baharudin., \& Rumpia, A. F. (2020). 2019-n cov-jangan takut virus corona. Yogyakarta: Rapha Publishing.

Dipna, V. (2020). Apa itu new normal dan bagaimana penerapannya saat pandemi corona?. https://tirto.id/apa-itu-new-normal-dan-bagaimana-penerapannyasaat-pandemi-corona-fCSg.

Keraf, G. (2009). Diksi dan gaya bahasa. Jakarta: PT. Gramedia Pustaka Utama.

Kurniawan, T. O. S. (2020). Soft skill komunikasi resepsionis. Oratio Directa, 2(2).

https://jakarta.bisnis.com/read/20200526/77/1244867/new-normal-dki-jakartaanies-tunggu-evaluasi-psbb-iii-kelar-4-juni).

https://www.kompas.com/skola/read/2019/12/27/150000569/pengertian-hoteldan-karakteristiknya?page $=$ all).

Putri, E. D. H. (2018). Pengantar akomodasi dan restoran. Deepublish.

Rahmayanti, W., \& Arifin, E. Z. (2020). Analisis gaya bahasa dan nilai pendidikan dalam novel Pulang karya Tere Liye. Diskursus: Jurnal Pendidikan Bahasa Indonesia, 3(01), 77-85.

Shabibie. (2020). Surat edaran nomor 2 tahun 2020 tentang pencegahan dan penanganan Coro/Va Y/Rus D/Sease (Covid-19) di Kementrian Pendidikan dan Kebudayaan. https://pusdiklat.kemdikbud.go.id/suratedaran-nomor-2-tahun-2o2o-tentang-pencegahan-dan-penanganan-corova-y-rus-d-sease-covid-19-di-kementerian-pendidikan-dan-kebudayaan/

Sinaga, F. (2018). Restoran dan kegiatannya. Yogyakarta: Penerbit Andi.

Sugiyono. (2016). Metode penelitian kuantitatif, kualitatif, dan R\&D. Bandung: Alfabeta.

Susilowati, E. S. E. (2016). Gaya bahasa dalam novel Pesantren Impian karya Asma Nadia. Jurnal Bastra (Bahasa dan Sastra), 2(1). 